\title{
PENGARUH PEMBERIAN EKSTRAK DAUN KELOR PADA IBU MENYUSUI EKSKLUSIF TERHADAP KENAIKAN BERAT BAYI 0 - 5 BULAN
}

\author{
Ratna Dewi Putri', Fitria ${ }^{2}$ \\ 1 Diploma IV Kebidanan Fakultas Kedokteran Universitas Malahayati \\ 2Diploma III Kebidanan Fakultas Kedokteran Universitas Malahayati \\ 1email Ratnadewi.070787@gmail.com \\ 2email aldita_samia@yahoo.com
}

\begin{abstract}
THE EFFECT OF MORINGA LEAVES EXTRACT ON EXCLUSIVE BREASTFEEDING MOTHER ON INFANT WEIGHT INCREASE IN 0 - 5 MONTHS
\end{abstract}

\begin{abstract}
Background: The nutritional needs of breastfeeding mothers are increased compared to non-breastfeeding and during pregnancy. Efforts to achieve optimal infant nutrition until they reach six months of age can only be done through improving maternal nutrition. This illustrates that the food consumed by breastfeeding mothers greatly affects the production of breast milk. Moringa leaves are a food ingredient that has a lactogenic effect because they contain phytosterols. National exclusive breastfeeding coverage has only reached $65.16 \%$, while exclusive breastfeeding coverage in Lampung province is $67.01 \%$ (Indonesian Ministry of Health 2018). Even though it has exceeded the national coverage, it is still low compared to the target target of $80 \%$. Meanwhile, in Bandar Lampung City, in 2018, exclusive breastfeeding coverage was 44.5\%. PWS KIA, Kebun Ginger Health Center, Bandar Lampung City, showed that from January to July 2019 there were 12,72\% babies under 6 months did not get optimal weight gain.

Purpose : To determine the effect of Moringa leaf extract on exclusive breastfeeding mothers on weight gain of infants 0-5 months at the Kebon Jahe Community Health Center in Bandar Lampung in 2020

Method: Quantitative research with a two group pretest-posttest design research method. The population was exclusively breastfeeding mothers, a sample of 32 mothers was divided into two groups. 16 breastfeeding mothers were given Moringa leaf extract and 16 breastfeeding mothers were given placebo, using purposive sampling technique. Data analysis was performed using statistical tests using independent $t$ test and paired $T$ test. Results: The average body weight in the group given Moringa leaves increased from 5012 grams to 5765.25 grams, while the group given katuk leaf extract increased from 4962 grams to 6040.62 grams. The results of the independent $T$ test obtained a $p$-value of 0.556 ( $p$ value $>0.05$ ), this means that statistically there is no difference in the two groups. Pairwise difference test results obtained $p$-value 0.000 (pvalue <0.05).

Conclusion: there is no difference in the effect of giving Moringa leaf extract and Katuk leaf (placebo) on weight gain in infants. There were differences in body weight before and after giving Moringa leaf extract and placebo. Moringa leaves have the same effectiveness in increasing baby weight.

Suggestion Based on the research results, the researchers suggest consuming a variety of foods that contain lactagogic effects such as Moringa leaves and Katuk leaves to help breast milk production. Midwives can provide health education during antenatal care regarding nutritional fulfillment with various types of food sources available, especially those containing lactagogum to increase breast milk production.
\end{abstract}

Keywords: breastfeeding, weight, moringa leaves

\section{ABSTRAK}

Latar Belakang : Kebutuhan gizi ibu menyusui meningkat dibandingkan dengan tidak menyusui dan masa kehamilan. Upaya pencapaian gizi bayi optimal hingga mencapai usia enam bulan hanya dapat dilakukan melalui perbaikan gizi ibu. Hal ini menggambarkan bahwa makanan yang dikonsumsi ibu menyusui sangat berpengaruh terhadap produksi ASI. Daun Kelor merupakan salah satu bahan makanan yang memiliki efek laktogogum karena mengandung fitosterol. Cakupan ASI eksklusif nasional baru mencapai 65,16\%, sedangkan cakupan ASI eksklusif di propinsi lampung sebesar $67,01 \%$ (Kemenkes RI 2018). Meskipun telah melampaui cakupan nasional namun masih rendah dibandingkan target sasaran sebesar 80\%. Sementara di Kota Bandar Lampung Tahun 2018 cakupan ASI eksklusif sebesar 44,5\% PWS KIA Puskesmas Kebun Jahe Kota Bandar Lampung menunjukkan 
dari Januari sampai Juli 2019 terdapat 12,72\% bayi dibawah 6 bulan yang tidak mengalami kenaikan berat badan optimal.

Tujuan penelitian : Diketahui pengaruh ekstrak daun kelor kepada ibu menyusui eksklusif terhadap kenaikan berat badan bayi 0-5 bulan di Puskesmas Kebon Jahe Bandar Lampung tahun 2020.

Metode : Penelitian kuantitatif dengan desain penelitian metode two group pretest-posttest design. Populasi adalah ibu menyusui eksklusif, sampel 32 ibu terbagi menjadi dua kelompok 16 ibu menyusui diberi ekstrak daun kelor dan 16 ibu menyusui diberikan placebo, teknik sampling purposive sampling. Analisis data dilakukan menggunakan uji statistik menggunakan uji t independent dan uji T berpasangan.

Hasil penelitian : rata rata berat badan pada kelompok yang diberi daun kelor mengalami peningkatan dari 5012 gram menjadi 5765,25 gram sedangkan pada kelompok yang diberikan ektrak daun katuk mengalami peningkatan 4962 gram menjadi 6040,62 gram. Hasil uji T independent diperoleh nilai p-value sebesar 0,556 ( $p$ value $>0,05$ ) hal ini bermakna bahwa secara statistik tidak ada perbedaan pada kedua kelompok. Hasil uji beda berpasangan diperoleh hasil pvalue 0,000 (pvalue $<0,05$ )

Kesimpulan : tidak ada perbedaan pengaruh pemberian ekstrak daun kelor dan daun katuk (placebo) terhadap kenaikan berat badan bayi. Ada perbedaan berat badan sebelum dan sesudah pemberian ekstrak daun kelor dan placebo. Daun kelor memiliki efektifitas yang sama dalam meningkatkan berat badan bayi.

Saran Berdasarkan hasil penelitian peneliti menyarankan untuk mengkonsumsi ragam makanan yang mengandung efek laktagogum seperti daun kelor dan daun katuk untuk membantu produksi ASI. Tenaga kesehatan khusus nya Bidan dapat memberikan pendidikan kesehatan selama antenatal care tentang pemenuhan gizi dengan beragam jenis sumber makanan yang tersedia khususnya yang mengandung laktagogum untuk meniningkatkan produksi ASI.

Kata Kunci: daun kelor, bayi, berat badan, ASI

\section{PENDAHULUAN}

ASI eksklusif (PP no 32 tahun 2012) adalah ASI yang diberikan kepada bayi sejak dilahirkan selama enam bulan, tanpa menambahkan dan/atau mengganti dengan makanan atau minuman lain (kecuali obat, vitamin, dan mineral). ASI mengandung berbagai zat gizi yang dibutuhkan dalam proses pertumbuhan dan perkembangan bayi serta merupakan makanan pertama dan terbaik yang bersifat alamiah. Adanya faktor protektif dan nutrien yang sesuai dalam ASI menjamin status gizi bayi baik serta kesakitan dan kematian anak menurun. Beberapa penelitian epidemiologis menyatakan bahwa ASI melindungi bayi dan anak dari penyakit infeksi seperti diare, otitis media, dan infeksi daluran pernapasan akut bagian bawah.

Kajian global "The Lancet Breastfeeding Series", 2016 telah membuktikan bahwa menyusui Eksklusif menurunkan angka kematian karena infeksi sebanyak $88 \%$ pada bayi berusia kurang dari 3 bulan, sebanyak 31,36\% (82\%) dari 37,94\% anak sakit, karena tidak menerima ASI Ekslusif. Investasi dalam pencegahan BBLR, Stunting dan meningkatkan IMD dan ASI Eksklusif berkontribusi dalam menurunkan risiko obesitas dan penyakit kronis (Patal, 2013). Tidak menyusui berhubungan dengan kehilangan nilai ekonomi sekitar \$302 milyar setiap tahunnya atau sebesar $0-49 \%$ dari Pendapatan Nasional Bruto (Lancet, 2016).
Di Indonesia Cakupan ASI eksklusif nasional baru mencapai $65,16 \%$, sedangkan cakupan ASI eksklusif di propinsi lampung sebesar 67,01\% (Kemenkes RI 2018). Meskipun telah melampaui cakupan nasional namun masih rendah dibandingkan target sasaran sebesar $80 \%$. Sementara di Kota Bandar Lampung Tahun 2018 cakupan ASI eksklusif sebesar 44,5\% (Dinkes Kota Bandar Lampung, 2018).

Kebutuhan gizi ibu menyusui meningkat dibandingkan dengan tidak menyusui dan masa kehamilan (kemenkes RI 2014). Ibu dalam 6 bulan pertama menyusui membutuhkan tambahan energi sebesar 500 kalori/hari untuk menhasilkan jumlah susu normal. Sehingga total kebutuhan energi selama menyusui meningkat menjadi 2400 kkal perhari yang akan digunakan untuk produkssi ASI dan aktifitas ibu sendiri (Dewi, 2013). Kebutuhan gizi bayi hingga usia enam bulan diperoleh melalui ASI. Produksi ASI yang cukup, baik jumlah dan kualitasnya sangat menentukan pertumbuhan bayi. Upaya pencapaian gizi bayi optimal hingga mencapai usia enam bulan hanya dapat dilakukan melalui perbaikan gizi ibu. Hal ini menggambarkan bahwa makanan yang dikonsumsi ibu menyusui sangat berpengaruh terhadap produksi ASI

Tanaman kelor (Moringa oleifera lamk) merupakan bahan makanan lokal yang memiliki potensi untuk dikembangkan dalam kuliner ibu menyusui, karena mengandung senyawa fitosterol 
yang berfungsi meningkatkan dan memperlancar produksi ASI (efek laktagogum). Secara teoritis, senyawa-senyawa yang mempunyai efek laktagogum diantaranya adalah sterol. Sterol merupakan senyawa golongan steroid (Zakaria, 2016). Daun kelor memiliki kandungan protein lengkap (mengandung 9 asam amino esensial), kalsium, zat besi, kalium, magnesium, zink dan vitamin $A, C, E$ serta $B$ yang memiliki peran besar pada sistem imun. Penelitian zakaria (2016) menunjukkan bahwa kuantitas ASI pada ibu yang diberikan ekstrak daun kelor meningkat secara signifikan dibandingkan dengan yang diberikan tepung daun kelor. PWS KIA Puskesmas Kebun Jahe Kota Bandar Lampung menunjukkan dari Januari sampai Juli 2019 terdapat 220 bayi dibawah 6 bulan dengan 28 diantaranya tidak mengalami kenaikan berat badan yang optimal. Tujuan dari penelitian ini adalah untuk mengetahui pengaruh pemberian ekstrak daun kelor terhadap kenaikan berat badan bayi.

\section{METODE PENELITIAN}

Penelitian ini penelitian kuantitatif dengan rancangan two group pretest-posttest design. Peneliti melakukan pemberian ekstrak daun kelor kepada kelompok eksperimen dan memberikan ekstrak daun katuk sebagai placebo pada kelompok kontrol. Pemberian treatmen selama 28 hari.

\section{HASIL DAN PEMBAHASAN}

Hasil Penelitian
Populasi dalam penelitian ini adalah seluruh ibu menyusui eksklusif bayi 0 - 5 bulan di wilayah kerja Puskesmas Kebun Jahe Bandar Lampung yang berjumlah 58 orang. Sampel dalam penelitian ini adalah ibu menyusui eksklusif bayi $0-5$ bulan pada saat penelitian. Teknik pengambilan sampel menggunakan purposive sampling dengan kriteria sampel

\section{Teknik Pengumpulan Data}

Pre test :Sebelum dilakukan perlakuan responden akan dilakukan penimbangan berat badan bayinya dengan menggunakan dacin di posyandu tempat responden tinggal. Perlakukan: responden dikelompokkan dalam dua kelompok, satu kelompok diberi intervensi berupa ekstrak daun kelor $600 \mathrm{mg} /$ hari selama 4 minggu. Pada kelompok kontrol diberikan intervensi berupa ekstrak daun katuk selama 4 minggu. Untuk memastikan konsumsi dengan teratur dan benar dilakukan pengecekan setiap hari via telepon atau melalui pengawas obat yang ditunjuk saat di rumah. Post Test :setelah 4 minggu dilakukan penimbangan kembali bayi responden baik kelompok intervensi maupun kelompok kontrol.

Tabel 1.

Hasil Uji T independen Kelompok setelah pemberian Kelor dan Placebo

\begin{tabular}{lccccc}
\hline \multicolumn{1}{c}{ Berat badan Bayi } & N & Mean & SD & SE & P value \\
\hline Kelompok Kelor & 16 & 5756.25 & 1237.184 & 309.296 & \multirow{2}{*}{0.556} \\
Kelompok Placebo & 16 & 6040.62 & 1457.763 & 364.441 & \\
\hline
\end{tabular}

Tabel 2.

Hasil Paired Sampel Test berat badan bayi sebelum dan sesudah pemberian treatment pada kedua kelompok

\begin{tabular}{lccccc}
\hline \multicolumn{1}{c}{ Berat badan Bayi } & N & Mean & SD & SE & P value \\
\hline Berat badan bayi sebelum pemberian treatment & 32 & 4978.12 & 1364.465 & 241.206 & \multirow{2}{*}{0.000} \\
Berat badan bayi setelah pemberian treatment & 32 & 5898.44 & 1337.817 & 236.495 & \\
\hline
\end{tabular}

\section{PEMBAHASAN}

Setelah 28 hari didapatkan data bahwa rata rata berat badan pada kelompok yang diberi daun kelor mengalami peningkatan dari 5012 gram menjadi 5765.25 gram sedangkan pada kelompok yang diberikan ektrak daun katuk mengalami peningkatan 4962 gram menjadi 6040,62 gram. Hasil uji $T$ independent diperoleh nilai $p$-value sebesar 0,556 ( $p$ value $>0,05$ ) sehingga hipotesis ditolak, hal ini bermakna bahwa secara statistik tidak ada perbedaan pada kedua kelompok.

Hasil uji beda berpasangan diperoleh hasil pvalue 0,000 (pvalue $<0,05$ ) menunjukkan hasil bahwa pemberian ekstrak daun kelor dan ekstrak daun katuk secara efektif mampu menaikkan produksi ASI dengan peningkatan berat badan bayi. Hal ini dapat dimaknai bahwa kedua bahan yang digunakan dalam dua kelompok memiliki pengaruh 
yang sama terhadap peningkatan produksi ASI yang dilihat dari penambahan berat badan pada bayi yang di beri ASI eksklusif.

Hasil penelitian ini sejalan dengan hasil penelitian Setiawandari (2017) yang menyatakan bahwa pemberian ekstrak daun katuk lebih efektif dari pada daun kelor dalam mempercepat pengeluaran kolostrum dan ASI pada ibu bersalin (pvalue : 0,026$)^{1}$.

Laktasi terjadi karena terdapat air susu sebagai hasil laktogenesis. Zat- zat yang terdapat dalam susu akan masuk kedalam tubuh anak melalui proses laktogenesis yang terjadi pada induk atau ibu. Laktogenesis merupakan suatu diferensiasi dari kelenjar ambing yang memiliki tiga fase. Fase pertama kelenjar ambing memproduksi kolostrum, yaitu berupa cairan kental kekuningan. Pada fase kedua terjadi peningkatan produksi ASI secara besar-besaran. Apabila payudara dirangsang, level prolaktik dalam darah meningkat dan keluarnya hormone prolactin akan menstimulasi sel di dalam alveoli untuk memproduksi air susu. Level prolactin rendah saat payudara terasa penuh. Hormone lainyya seperti insulin, tiroksin dan kkortisol juda terdapat dalam prosesini, namun peran hormone hormone tersebut belum diketahui. Ketika produksi ASI mulai stabil, system control autokrin dimulai. Pada fase ini, apabila ASI banyak dikeluarkan maka payudara akan memproduksi ASI dengan banyak pula.

Selama kehamilan, hormon esterogen dan progesteron menginduksi (membangkitkan) perkembangan alveolus dan duktus duktus laktiferus (Lctiferous duct) didalam mamae (payudara), di asmping menstimulasi (merangsang) produksi kolostrum. Namun demikian saat itu belum ada produksi ASI. Sesudah bayi dilahirkan, disusul kemudian terjadinya peristiwa penurunan kadar hormon esterogen. Penurunan kadar esterogen ini mendorong naiknya kadar prolaktin. Naiknya kadar prolaktin, mendorong produksi ASI. Maka dengan naiknya prolaktin tersebut, mulailah aktivitas produksi ASI berlangsung. Ketika bayi mulai menyusu pada ibunya, aktivitas bayi menyusu pada mamae ini menstimulasi terjadinya produksi prolaktin yang terus-menerus secara berkesinambungan. Sekresi ASI sendiri, berada dibawah pengaruh atau dikendalikan oleh neuro-endokrin. Rangsangan sentuhan pada payudara yakni ketika bayi menghisap puting susu menyebabkan timbulnya rangsangan yang menyebabkan terjadiya produksi oksitosin. Oksitosin merangsang terjadinya kontraksi sel-sel mioepitel. Proses ini disebut refleks "let down" atau "pelepasan ASI" setelah berlangsung beberapa hari, emosi ibu dapat berpengaruh pada fisiologi pengeluaran ASI. Sebagai contoh, rasa takut, lelah, malu, pendek kata kondisi sterss pada ibu, dapat menghambat pelepasan ASI keluar payudara. Pada tahap awal emosi ibu tersebut sama sekali tidak berpengaruh. Baru setelah bayi menghisap ASI pada hari-hari berikutnya, (tidak sama pada setiap ibu, hari keberapa) maka emosi ibu berpengaruh pada pelepasan ASI tersebut.

Hisapan bayi pada mammae ibu dapat merangsang atau memicu pelepasan ASI dari alveolus mammae melalui duktus ke sinus laktiferus. Secara fisiologis, hisapan bayi pada mammae ibu, merangsang produksi oksitosin oleh kelenjar hipofisis posterior. Oksitosin memasuki darah dan menyebabkan kontraksi sel-sel khusus (sel-sel mioepitel) yang mengelilingi alveolus mammae dan duktus laktiferus dan disana ASI tersebut akan disimpan. Pada saat bayi menghisap puting payudara, ASI didalam sinus tertekan keluar, ke mulut bayi. Gerakan ASI dan sinus ini dinamakan "let down" atau pelepasan.

Berbagai factor dapat mempengaruhi proses menyusui, antara lain faktor kejiwaan semakin tinggi tingkat gangguan emosional ibu makan semakin sedikit rangsangan hormone prolactin dalam tubuh sehingga menurunkan produksi ASI( Amalia, 2015). Selain itu juga gangguan psikologis akan menurunkan sekresi hormone oksitosin yang bermanfaat dalam proses laktasi (sulastri, 2016). Faktor-faktor yang berhubungan dengan produksi ASI yaitu faktor makanan yaitu kebutuhan kalori ibu perhari harus terdiri dari $60-70 \%$ karbohidrat, 10 $20 \%$ protein, dan $20-30 \%$ lemak. Kalori ini diperoleh dari makanan yang dikonsumsi ibu dalam sehari (Nutrisi Bangsa, 2013)

Kebutuhan gizi ibu menyusui meningkat dibandingkan dengan tidak menyusui dan masa kehamilan (kemenkes RI 2014)3. I Ibu dalam 6 bulan pertama menyusui membutuhkan tambahan energi sebesar 500 kalori/hari untuk menhasilkan jumlah susu normal. Sehingga total kebutuhan energi selama menyusui meningkat menjadi 2400 kkal perhari yang akan digunakan untuk produkssi ASI dan aktifitas ibu sendiri (Dewi, 2013)4. Kebutuhan gizi bayi hingga usia enam bulan diperoleh melalui ASI. Produksi ASI yang cukup, baik jumlah dan kualitasnya sangat menentukan pertumbuhan bayi. Upaya pencapaian gizi bayi optimal hingga mencapai usia enam bulan hanya dapat dilakukan melalui perbaikan gizi ibu. Hal ini menggambarkan bahwa makanan yang dikonsumsi ibu menyusui sangat berpengaruh terhadap produksi $\mathrm{ASI}^{4}$

Tanaman kelor (Moringa oleifera lamk) merupakan bahan makanan lokal yang memiliki potensi untuk dikembangkan dalam kuliner ibu 
menyusui, karena mengandung senyawa fitosterol yang berfungsi meningkatkan dan memperlancar produksi ASI (efek laktagogum). Secara teoritis, senyawa-senyawa yang mempunyai efek laktagogum diantaranya adalah sterol. Sterol merupakan senyawa golongan steroid (Zakaria, 2016). Daun kelor memiliki kandungan protein lengkap (mengandung 9 asam amino esensial), kalsium, zat besi, kalium, magnesium, zink dan vitamin $A, C, E$ serta $B$ yang memiliki peran besar pada sistem imun. Penelitian zakaria (2016) menunjukkan bahwa kuantitas ASI pada ibu yang diberikan ekstrak daun kelor meningkat secara signifikan dibandingkan dengan yang diberikan tepung daun kelor ${ }^{5,2}$. Laktagogum memiliki potensi dalam menstimulasi hormon oksitoksin dan prolaktin seperti alkaloid, polifenol, steroid, flavonoid dan substansi lainnya paling efektif dalam meningkatkan dan memperlancar produksi ASI.

Hasil penelitian Widowati (2018) menyatakan bahwa pemberian ekstrak biji klabet dan daun kelor pada tikus betina memiliki potensi 2,4 kali lipat mampu meningkatkan produksi ASI dibandingkan pada kelompok tikus yang tidak mendapatkan ekstrak biji klabet dan daun kelor ${ }^{6}$. Hasil penelitian yang dikutip oleh Warta Puslitbang Perkebunan (2014) mengatakan bahwa daun katuk dikenal sebagai tanaman perangsang ASI, karena mengandung sterol (dengan turunanya fitosterol) dan polifenol yang dapat meningkatkan kadar hormon prolaktin untuk memproduksi ASI, merangsang hormon desitosin untuk memacu pengeluaran dan pengaliran ASI, serta memiliki efek laktogogum yang dapat meningkatkan jumlah dan mutu ASI karena mengandung zat yang bersifat fitosterol $446 \mathrm{mg} / 100 \mathrm{~g}$. Demikian juga dengan tanaman kelor, di Indonesia tanaman kelor disebut sebagai pohon ajaib karena memiliki banyak manfaat bagi manusia, diantaranya untuk ibu menyusui. Sama halnya dengan daun katuk, daun kelor mengandung senyawa fistosterol yang berfungsi meningkatkan dan melancarkan produksi ASI (efek laktogogum). Kandungan nutrisi yang luar biasa pada kelor, dimanfaatkan tidak hanya untuk ibu hamil dan menyusui, tetapi juga untuk mengatasi masalah malnutrisi pada balita. Dalam daun kelor mengandung $\mathrm{Fe} 5,49 \mathrm{mg} / 100 \mathrm{~g}$, dan fitosterol yaitu sitosterol 1,15\%/100 g dan stigmasterol 1,52\%/100 g yang dapat merangsang produksi ASI (Warta Puslitbang Perkebunan, 2014).

Menurut peneliti berdasarkan hasil penelitian yang telah diperoleh ekstrak daun kelor memiliki khasiat yang sama dalam produksi ASI dengan placebo yang digunakan yaitu ekstrak daun katu. Kemudahan memperoleh tanaman lokal tersebut juga dapat menjadi nilai tambah sebagai alternatif makanan untuk ibu menyusui. Keduanya memiliki efek laktagogum yang dapat menstimulasi produksi ASI dan meningkatkan berat badan bayi sehingga dapat mencegah kejadian stunting pada bayi. Konsumsi tanaman ini juga dapat dimulai dari trimester tiga kehamilan sebagai persiapan menyusui. Disarakan kepada ibu menyusui agar dapat memenuhi kebutuhan nutrisi dengan aneka ragam bahan makanan dan sayur yang tersedia terutama nya yang memiliki efek laktogogum seperti daun kelor.

\section{KESIMPULAN}

Berdasarkan hasil penelitian dan pembahasan, maka dapat diambil kesimpulan bahwa: rata-rata (mean) berat badan bayi sebelum diberikan ekstrak daun kelor 5012,5 gram dan sesudah pemberian 5756,25 gram,rata-rata (mean) berat badan bayi sebelum diberikan ekstrak daun katuk (placebo) 4962,5 gram dan sesudah pemberian 6040,62 gram,tidak ada perbedaan pengaruh antara pemberian ekstrak daun kelor dan daun katuk (placebo ) dalam meningkatkan berat badan bayi $0-5$ bulan.

\section{SARAN}

Berdasarkan hasil penelitian peneliti menyarankan untuk mengkonsumsi ragam makanan yang mengandung efek laktagogum seperti daun kelor dan daun katuk untuk membantu produksi ASI. Tenaga kesehatan khusus nya Bidan dapat memberikan pendidikan kesehatan selama antenatal care tentang pemenuhan gizi dengan beragam jenis sumber makanan yang tersedia khususnya yang mengandung laktagogum untuk meniningkatkan produksi ASI.

\section{DAFTAR PUSTAKA}

Amalia, R. 2016. Hubungan Sters Dengan Kelancaran ASI Pada Ibu Menyusui Pasca Persalinan di RSI A. Yani Surabaya. Jurnal Ilmiah Kesehatan, Vol. 8, No. 1, Februari 2016: $12-16$

Asih, Y. Risneni. 2016. Buku Ajar Asuhan Kebidanan Nifas Dan Menyusui. Jakarta: Trans Info Media.

Dewi, A.B.F.K., Pujiastuti, N., Fajar, I. 2013. IImu Gizi untuk Praktisi Kesehatan. Yogyakarta: Graha IImu. Hal 30-35

Dinas Kesehatan Provinsi Lampung. 2018. Profil Kesehatan Provinsi Lampung. pemerintah Provinsi Lampung

Kemenkes RI .2018.Data dan Infomasi profil Kesehatan Indonesia tahun 2018. 
Kementrian Kesehatan RI

Kemenkes RI.2018. Pedoman Pekan ASI Sedunia (PAS) tahun 2018. Kementrian Kesehatan RI

Kemenkes RI. 2014. Pedoman Gizi Seimbang. Kementrian Kesehatan RI: Direktorat Bina Gizi

Notoatmodjo, S. (2010). Metodologi penelitian kesehatan.

Pusdatin Kemenkes RI .2014. Situasi dan Analisis ASI eksklusif. Kementrian Kesehatan RI

Septadina, I. S., Murti, K., \& Utari, N. (2018). Efek Pemberian Ekstrak Daun Kelor (Moringa oleifera) dalam Proses Menyusui. Sriwijya Journal of Medicine, 1 (1), Januari 2018, 74,79

Setiawandari, Istiqomah (2017). EFEKTIFITAS EKSTRAK SAUROPUS ANDROGYNUS (DAUN KATUK) DAN EKSTRAK MORINGA OLEIFERA LAMK (DAUN KELOR) TERHADAP PROSES PERSALINAN, PRODUKSI KOLOSTRUMDAN PROSES INVOLUSI UTERI IBU POSTPARTUM. Embryo Jurnal Kebidanan, IX (1) November 2017,16,23

Soetjiningsih.1995.ASI petunjuk untuk tenaga kesehatan. Jakarta : EGC

Supranto, J. (2007). Teknik sampling survey \& eksperimen. Rineka Cipta, Jakarta, 33-41

Sulastri, W. 2016. Hubungan Tingkat Kecemasan Ibu
Dengan Pemberian ASI Pada Masa Nifas Di Puskesmas Umbulhardjo 1 Yogyakarta Tahun 2016. Jurnal Imiah Tingkat Kecemasan Dengan Pemberian ASI. 2016 : 1-8

Victora, C. G., Bahl, R., Barros, A. J., França, G. V., Horton, S., Krasevec, J., ... \& Group, T. L. B. S. (2016). Breastfeeding in the 21st century: epidemiology, mechanisms, and lifelong effect. The Lancet, 387(10017), 475-490

Warta Puslitbang Perkebunan (Puslitbangbun) Vol. 20 No. 3, 2014. Pemanfaatan tanaman Kelor (Moringa oleifera) Untuk Meningkatkan Produksi Air Susu Ibu. http://perkebunan.litbang.pertanian.go.id/?p= 11232

Widowati, L., Isnawati, A., Alegantina, S., \& Retiaty, F. (2019). Potensi ramuan ekstrak biji klabet dan daun kelor sebagai laktagogum dengan nilai gizi tinggi. Media Penelitian dan Pengembangan Kesehatan, 29(2), 143-152.

Zakaria, Z., Hadju, V., As' ad, S., \& Bahar, B. (2016). PENGARUH PEMBERIAN EKSTRAK DAUN KELOR TERHADAP KUANTITAS DAN KUALITAS AIR SUSU IBU (ASI) PADAIBU MENYUSUI BAYI 0-6 BULAN. Media Kesehatan Masyarakat Indonesia, 12(3), 161-169. 